\title{
GAYA KOMUNIKASI CALON KEPALA DAERAH MENJELANG PILKADA PADA MEDIA SOSIAL INSTAGRAM
}

\author{
Renata Anisa ${ }^{1}$, Rachmaniar ${ }^{2}$ \\ Prodi Ilmu Komunikasi, Fakultas Ilmu Komunikasi, Universitas Padjadjaran \\ renata@unpad.ac.id
}

\begin{abstract}
ABSTRAK
Pemilihan kepala daerah di Indonesia akan dilaksanakan serentak pada Juni 2018, calon kepala daerah berkompetisi untuk mendapatkan perhatian dan simpati publik, diantaranya dengan komunikasi melalui media sosial. Pada media sosial para calon kepala daerah menginformasikan visi, misi, program kerja, menampung aspirasi publik, dan berkomunikasi secara langsung dengan masyarakat menggunakan gaya komunikasi masing-masing calon. Penelitian ini bertujuan untuk mengetahui bagaimana gaya komunikasi yang digunakan calon kepala daerah Jawa Barat Ridwan Kamil (RK) menjelang pilkada pada media instagram. Penelitian ini menggunakan studi dokumentasi dengan menganalisis gaya komunikasi yang digunakan calon kepala daerah dalam berkomunikasi dengan netizen. Pengambilan data dilakukan dengan partisipasi observasi. Hasil penelitian menunjukkan gaya komunikasi yang digunakan calon kepala daerah Ridwan Kamil (RK) pada media sosial instagram adalah gaya komunikasi dua arah (The Equalitarian Style). Hal tersebut dapat dilihat dari komunikasi dan penyampaian pesan yang bersifat dua arah. Komunikasi yang dilakukan bersifat informal dan terbuka dimana netizen dapat mengakses akun calon kepala daerah dan menyampaikan opini, kritik, gagasan, dan dukungan secara langsung. Calon kepala daerah menggunakan media sosial untuk berkomunikasi dengan netizen secara langsung, menyampaikan program kerja, informasi kunjungan ke berbagai daerah, informasi agenda debat pilkada, serta kegiatan lainnya. Pada setiap informasi yang diunggah akun RK ini mampu memperoleh komentar netizen sebanyak seratus hingga empat ribu baik positif maupun negatif.
\end{abstract}

Kata kunci: Media, media sosial, instagram, studi dokumentasi, gaya komunikasi

\begin{abstract}
The election of head of region in Indonesia will be held in June 2018, the candidates compete to get public attention and sympathy with communication through social media. On social media, the candidates can informs the vision, mission, programs, accommodate the public aspirations, and communicate directly to the public with style of communication of each candidates. This research aims to find how communication style used by the candidate ahead of the elections on instagram. This research uses document studies method by analyzing communication style that used a candidate's in communicating with netizen. This research uses observation and participation in collect data. The results showed that communication style used by the candidate Ridwan Kamil on social media instagram ia a two way communication style (The Equalitarian Style). It can be seen from the communication and the delivery of messages that are twoway. Communication conducted informal and open, where the netizen can access the candidate account and expressed their opinion, criticism, ideas, and support directly. The candidate using social media to communicate with public directly, describe their programs, information visits to regions, election debate agenda information, and other activities. On any information uploaded by RK account is able to acquire as many as a hundred netizen comments up to four thousand both positive and negative.
\end{abstract}

Keywords : Media, Social Media, instagram, document studies, style of communication.

\footnotetext{
2. Prodi Ilmu Komunikasi, Fakultas Ilmu Komunikasi, Universitas Padjadjaran rachmaniar@unpad.ac.id.
} 


\section{PENDAHULUAN}

Pemilihan kepala daerah serentak di Indonesia akan diselenggarakan pada Juni 2018. Calon kepala daerah beramai ramai mendapatkan simpati publik melalui komunikasi, baik tatap muka maupun melalui media, salah satu media yang banyak digunakan adalah media sosial diantaranya adalah facebook, twitter, instagram, dan youtube. Melalui media sosial para calon kepala daerah menginformasikan visi, misi, program kerja, menampung aspirasi publik, dan berkomunikasi secara langsung dengan masyarakat. Beberapa calon kepala daerah menginformasikan kegiatan-kegiatan menjelang pilkada melalui media facebook dan instagram. Menurut Ketua Komisi Pemilihan Umum Arief Budiman pada halaman kompas, masa kampanye kepala daerah dimulai pada 15 Februari 2018 dan masa tenang dan pembersihan alat peraga akan dimulai pada 24 Juni 2018.

Sementara itu, Komisi Pemilihan Umum Provinsi Jawa Barat telah secara resmi menetapkan empat pasangan calon kepala daerah. Pada halaman Pikiran Rakyat disebutkan keempat pasangan calon tersebut yaitu pasangan Rindu, Ridwan Kamil- Uu Ruzhanul Ulum yang diusung oleh NasDem, PPP, PKB dan Hanura, pasangan calon 2 DM Deddy Mizwar, Dedi Mulyadi yang didukung oleh Golkar dan Demokrat. Kemudian pasangan calon Asyik Sudrajat-Ahmad Syaikhu yang diusung oleh PKS, PAN, dan Gerindra, serta Pasangan Hasanah Hasanuddin dan Anton Charliyan yang didukung oleh PDIP. Ridwan Kamil yang merupakan walikota Bandung adalah salah satu kepala daerah yang aktif menggunakan sosial media, khususnya media instagram.

Perkembangan teknologi dan informasi di Indonesia memberikan peluang kepada para calon kepala daerah untuk dapat dengan mudah dan cepat berkomunikasi secara langsung dengan masyarakat. Menurut data resmi Kementrian Komunikasi dan Informatika jumlah pengguna internet di Indonesia diperkirakan akan mencapai 112 juta jiwa. Sementara Asosiasi Penyelenggara Jasa Internet Indonesia (APJII) menyebutkan Facebook menempati posisi pertama sebagai media sosial terpopuler atau terbanyak dikunjungi pengguna internet di Indonesia. Instagram di posisi media sosial terpopuler kedua dan Youtube menempati posisi tiga. Selain itu data CNN Indonesia menyebutkan pengguna aktif instagram di Indonesia mencapai 22 juta.

Pendiri instagram Kevin Systrom dan Mike Kriege, Kata "insta” berasal dari kata "instan", seperti kamera polaroid yang pada masanya lebih dikenal dengan sebutan "foto instan". Instagram juga dapat menampilkan foto-foto secara instan, seperti polaroid di dalam tampilannya. Sedangkan untuk kata "gram" berasal dari kata "telegram", dimana cara kerja 
telegram sendiri adalah untuk mengirimkan informasi kepada orang lain dengan cepat. Sehingga dapat disimpulkan bahwa Instagram adalah aplikasi berbagi foto, video dengan menggunakan jaringan internet, sehingga informasi yang ingin disampaikan dapat diterima dengan cepat dengan jangkauan yang luas.

Instagram sebagai media yang populer di Indonesia kerap digunakan masyarakat untuk bersosialisasi, tidak terkecuali pejabat dan politisi untuk berkomunikasi dengan publik. Media sosial saat ini dinilai cukup efektif dalam membangun komunikasi dan menyebarkan informasi. Melalui media sosial pejabat publik dapat menginformasikan berbagai aktivitas, kebijakan, fasilitas publik serta menampung masukan, aspirasi, kritik dalam waktu yang relatif singkat. Menurut Van Dijk (2013) dalam Nasrullah media sosial adalah platform media yang memfokuskan pada eksistensi pengguna yang memfasilitasi mereka dalam beraktivitas maupun berkolaborasi. Karena itu, media sosial dapat dilihat sebagai medium (fasilitator) online yang menguatkan hubungan antar pengguna sekaligus sebagai sebuah ikatan sosial.

Sementara Shirky (2008) mengemukakan media sosial dan perangkat lunak sosial merupakan alat untuk meningkatkan kemampuan pengguna untuk berbagi (to share), bekerja sama (to cooperate) di antara pengguna dan melakukan tindakan secara kolektif yang semuanya berada di luar kerangka institusional maupun organisasi. Berikutnya Mieke dan Young (2012) mengartikan kata media sosial sebagai konvergensi antara komunikasi personal dalam arti saling berbagi di antara individu (to be shared one-to-one) dan media publik untuk berbagi kepada siapa saja tanpa ada kekhususan individu. (Nasrullah: 2017). Dari beberapa pengertian diatas dapat dikatakan bahwa media sosial adalah media komunikasi antara pengguna media sosial dengan netizen secara umum. Pengguna media sosial dapat berkomunikasi secara langsung dengan netizen dengan fitur-fitur pada media sosial seperti komentar, pesan langsung, online chat, dan mention. Netizen dapat dengan mudah dan cepat menyampaikan pesan dan informasi kepada pemilik akun di media sosial. Bahkan beberapa media sosial saat ini dilengkapi dengan fitur live, dimana pengguna media dapat mengunggah video secara langsung (live) saat melakukan aktivitas dalam waktu yang sama, fitur ini dapat dilihat oleh netizen lainnya dalam kurun waktu 24 jam dengan durasi yang tidak dibatasi.

Menurut Mulyati (2014) Kelebihan media sosial adalah sebagai berikut : (1) Cepat, ringkas, padat dan sederhana. Medsos begitu mudah digunakan (user friendly), bahkan pengguna tanpa basis pengetahuan Teknologi Informasi (TI) pun dapat menggunakannya. Yang diperlukan hanya komputer, tablet, smartphone, ditambah koneksi internet. (2) Menciptakan hubungan lebih intens. Medsos memberikan kesempatan yang lebih luas kepada user untuk berinteraksi 
dengan mitra, pelanggan, dan relasi, serta membangun hubungan timbal balik secara langsung dengan mereka. (3) Jangkauan luas dan global. Melalui medsos, siapa pun bisa mengkomunikasikan informasi secara cepat tanpa hambatan geografis. Pengguna medsos juga diberi peluang yang besar untuk mendesain konten, sesuai dengan target dan keinginan ke lebih banyak pengguna. (4) Kendali dan terukur. Dalam medsos dengan sistem tracking yang tersedia, pengguna dapat mengendalikan dan mengukur efektivitas informasi yang diberikan melalui respons balik serta reaksi yang muncul. (Mulyati, 2014:31).

Sementara menurut Nasrullah karakteristik media sosial, yaitu (1) jaringan, (2) informasi, (3) arsip, (4) interaksi, (5) simulasi sosial, (6) konten oleh pengguna. Di media sosial, khalayak merupakan khalayak aktif. Tidak hanya mengonsumsi atau menggunakan konten, tetapi juga memproduksi dan menyebarkan konten. (Nasrullah:2017).

Berikutnya, Nasrullah (2017) menyimpulkan bahwa setidaknya ada enam kategori besar untuk melihat pembagian media sosial, yakni :

1) Media jejaring sosial (social networking)

2) Jurnal online (blog)

3) Jurnal online sederhana atau mikroblog (micro-blogging)

4) Media berbagi (media sharing)

5) Penanda sosial (social bookmarking)

6) Media konten bersama atau wiki.

Gaya komunikasi dalam media sosial instagram merupakan gaya berkomunikasi pengguna instagram yang berperan sebagai komunikator kepada netizen sebagai komunikan di dunia maya. Gaya komunikasi seseorang dalam berinteraksi di media sosial bersifat dinamis, artinya dapat berubah dipengaruhi oleh faktor psikologis dan kepentingan masing-masing pengguna media sosial. Menurut Steward L.Tubbs dan Sylvia Moss (1996) terdapat enam gaya komunikasi yaitu :

1. Gaya komunikasi mengendalikan (The Controling Style) ditandai dengan adanya satu kehendak atau maksud untuk membatasi, memaksa dan mengatur perilaku, pikiran dan tanggapan orang lain. Orang-orang yang menggunakan gaya komunikasi ini dikenal dengan nama komunikator satu arah atau one way communications

2. Gaya komunikasi dua arah (The Equalitarian Style) Dalam gaya komunikasi ini, tindak komunikasi dilakukan secara terbuka. Artinya setiap anggota dapat mengungkapkan gagasan ataupun oendapat dalam suasana yang rileks, santai dan informal. Dalam 
suasana yang demikian, memungkinkan setiap anggota organisasi mencapai kesepakatan dan pengertian bersama.

3. Gaya komunikasi terstuktur (The Structuring style), Gaya komunikasi yang berstruktur ini, memanfaatkan pesan-pesan verbal secara tertulis maupun lisan guna memantapkan perintah yang harus dilaksanakan, penjadwalan tugas dan pekerjaan serta struktur organisasi. Pengirim pesan lebih memberi perhatian kepada keinginan untuk mempengaruhi orang lain dengan jalan berbagi informasi.

4. Gaya komunikasi dinamis (The Dynamic Style), Gaya komunikasi yang dinamis ini memiliki kecenderungan agresif, karena pengirim pesan atau sender memahami bahwa lingkungan pekerjaannya berorientasi pada tindakan (action-oriented).

5. The Relinguishing Style, Gaya komunikasi ini lebih mencerminkan kesediaan untuk menerima saran, pendapat ataupun gagasan orang lain, daripada keinginan untuk memberi perintah, meskipun pengirim pesan mempunyai hak untuk memberi perintah dan mengontrol orang lain.

6. The Withdrawal Style, Akibat yang muncul jika gaya ini digunakan adalah melemahnya tindak komunikasi, artinya tidak ada keinginan dari orang-orang yang memakai gaya ini untuk berkomunikasi dengan orang lain, karena ada beberapa persoalan ataupun kesulitan antarpribadi yang dihadapi oleh orang-orang tersebut.

Merujuk pada penelitian sebelumnya yang berjudul "Bandung Citizen Perceptions Related to Communication Styles of Ridwan Kamil in Social Media” disimpulkan bahwa gaya komunikasi yang digunakan Ridwan Kamil dalam berkomunikasi dengan publik melalui media sosial adalah the equalitarian style, dimana karakteristik utama dari gaya komunikasi ini adalah dua arah dengan cara penyampaian yang terbuka dan bersifat informal.

Maraknya pemilihan kepala daerah yang dilaksanakan serentak di Indonesia menarik perhatian penulis untuk mengetahui bagaimana gaya komunikasi calon kepala daerah Jawa Barat Ridwan Kamil (RK) menjelang pemilihan kepala daerah pada media sosial instagram, menurut beberapa survey elektabilitas Ridwan Kamil sebagai calon kepala daerah di Jawa Barat cukup tinggi dibandingkan calon lainnya.

\section{METODE PENELITIAN}

Penelitian ini menggunakan pendekatan kualitatif dengan studi dokumentasi. Pendekatan kualitatif terutama layak untuk menelaah sikap atau perilaku dalam lingkungan yang agak artifisial, seperti dalam survei atau eksperimen. (Mulyana, 2007:11).

53 SOSIOGLLBAL : Jurnal Pemikiran dan Penelitian Sasiologi, Vol. 2, №. 2, Juni 2018 
Menurut Danial dalam Metode Penulisan Karya Ilmiah, studi dokumentasi adalah pengumpulan berbagai dokumen yang dibutuhkan untuk bahan data informasi terkait masalah penelitian, mencakup peta, data statistik, jumlah dan nama pegawai, data siswa, data penduduk, grafik, gambar, surat - surat, foto, akte, dan lain sebagainya. Sementara menurut Sugiyono dalam Metode Penelitian Pendidikan Pendekatan Kuantitatif, Kualitatif dan R \& D, studi dokumentasi adalah sebuah teknik untuk mengumpulkan data melalui cara mempelajari dokumen agar memperoleh data atau informasi yang terkait dengan masalah yang sedang diteliti.

Studi dokumen adalah teknik pengumpulan data melalui pengumpulan dan penganalisisan dokumen-dokumen, mencakup dokumen tertulis, gambar, hasil karya, maupun elektronik. Dokumen yang didapat lalu dianalisis, diperbandingkan, dan disatukan (sintesis) menghasilkan sebuah bahan yang runut, menyatu, dan utuh. Studi dokumenter bukan hanya menyatukan dan menuliskan atau menyampaikan sesuatu dengan cara mengutip dokumen-dokumen, tetapi juga melaporkan hasil penelitian dengan cara menganalisis dokumen-dokumen tersebut.

\section{HASIL DAN PEMBAHASAN}

Calon Kepala Daerah Jawa Barat Ridwan Kamil atau biasa disingkat RK yang juga merupakan walikota Bandung periode 2013-2018 menggunakan akun instagram@ridwankamil dengan jumlah pengikut atau followers 7,7juta dan mengikuti lebih dari 1600 akun. Jumlah unggahan hingga februari 2018 adalah sebanyak 4,709 unggahan/post. Media lainnya yang digunakan RK adalah facebook, twitter, dan blog pribadi. Melalui akun instagram RK mampu menjangkau lebih dari 7 juta masyarakat dari berbagai kalangan, sementara pada akun twitter @ ridwankamil memiliki jumlah pengikut hingga 3,1 juta. Pada media facebook RK memiliki pengikut sebanyak 3,3 juta. Melalui akun-akun media sosial tersebut RK mampu menjangkau lebih dari 13 juta netizen. Setiap informasi yang disampaikan melalui unggahan pada media sosial tersebut dapat diterima oleh setidaknya 13 juta netizen dalam waktu yang sama. Unggahan pada media facebook dan instagram dilengkapi dengan audio, foto dan video, sehingga informasi disampaikan dengan lengkap dan cukup jelas. Profil RK sebagai calon kepala daerah disampaikan dengan cukup menarik dengan durasi 4 menit. RK juga membuat profil untuk beberapa kota dan kabupaten di Jawa Barat. Sementara pada media twitter informasi disampaikan dengan singkat, beberapa dilengkapi dengan unggahan foto dan video, RK juga memberikan respon langsung kepada netizen yang mengajukan pertanyaan melalui twitter. Secara umum informasi-informasi yang diunggah pada media sosial tersebut memiliki konten yang relatif sama, namun dikemas dengan cara yang berbeda. Sebagian besar informasi tersebut diunggah secara langsung oleh RK dan beberapa lainnya oleh tim admin. 
Tabel 1. Media resmi calon kepala daerah Ridwan Kamil

\begin{tabular}{cllccc}
\hline \hline No. & Jenis Media & Akun & $\begin{array}{c}\text { Tahun } \\
\text { Berdiri }\end{array}$ & $\begin{array}{c}\text { Jumlah } \\
\text { followers }\end{array}$ & $\begin{array}{c}\text { Unggahan/ } \\
\text { Post }\end{array}$ \\
\hline 1. & Twitter & @ ridwankamil & 2009 & 3,01 juta & 42,1 ribu \\
\hline 2. & Instagram & @ ridwankamil & 2015 & 7,7 juta & 4,7 ribu \\
\hline 3. & Facebook & Ridwan Kamil & - & 3,3 Juta & - \\
\hline 4. & Blog & ridwankamil.wordpress.com & 2008 & - & -
\end{tabular}

Sumber : Hasil Penelitian, 2018

Informasi yang disampaikan RK melalui media sosial instagram ditampilkan dengan lebih jelas, karena dilengkapi dengan keterangan gambar dan audio serta visualisasi gambar, foto, maupun video. Informasi yang diunggah pada instagram mencapai 4,7 ribu unggahan. Informasi yang disampaikan pada umumnya adalah informasi kegiatan pemkot Bandung, program kerja, prestasi, kebijakan pemerintah, sosialisasi aturan, fasilitas publik, dan kegiatan pribadi RK. Namun pada penelitian ini difokuskan pada gaya komunikasi yang digunakan RK pada media instagram menjelang pilkada dimana RK secara resmi sudah tidak menjabat sebagai walikota Bandung dan bertarung pada pilkada Jawa Barat 2018. Jumlah unggahan pada instagram @ ridwankamil menjelang pilkada berjumlah 50 unggahan. Lebih dari 40\% konten unggahan pada instagram RK berkaitan dengan pilkada seperti kegiatan kunjungan ke beberapa daerah di Jawa Barat dalam rangka memperoleh dukungan warga, kegiatan sosial bagi warga yang mendapatkan musibah, informasi acara debat cagub, serta sosialisasi program kerja. Sementara unggahan lainnya berkaitan dengan kegiatan-kegiatan yang bersifat pribadi dan informasi yang mengibur.

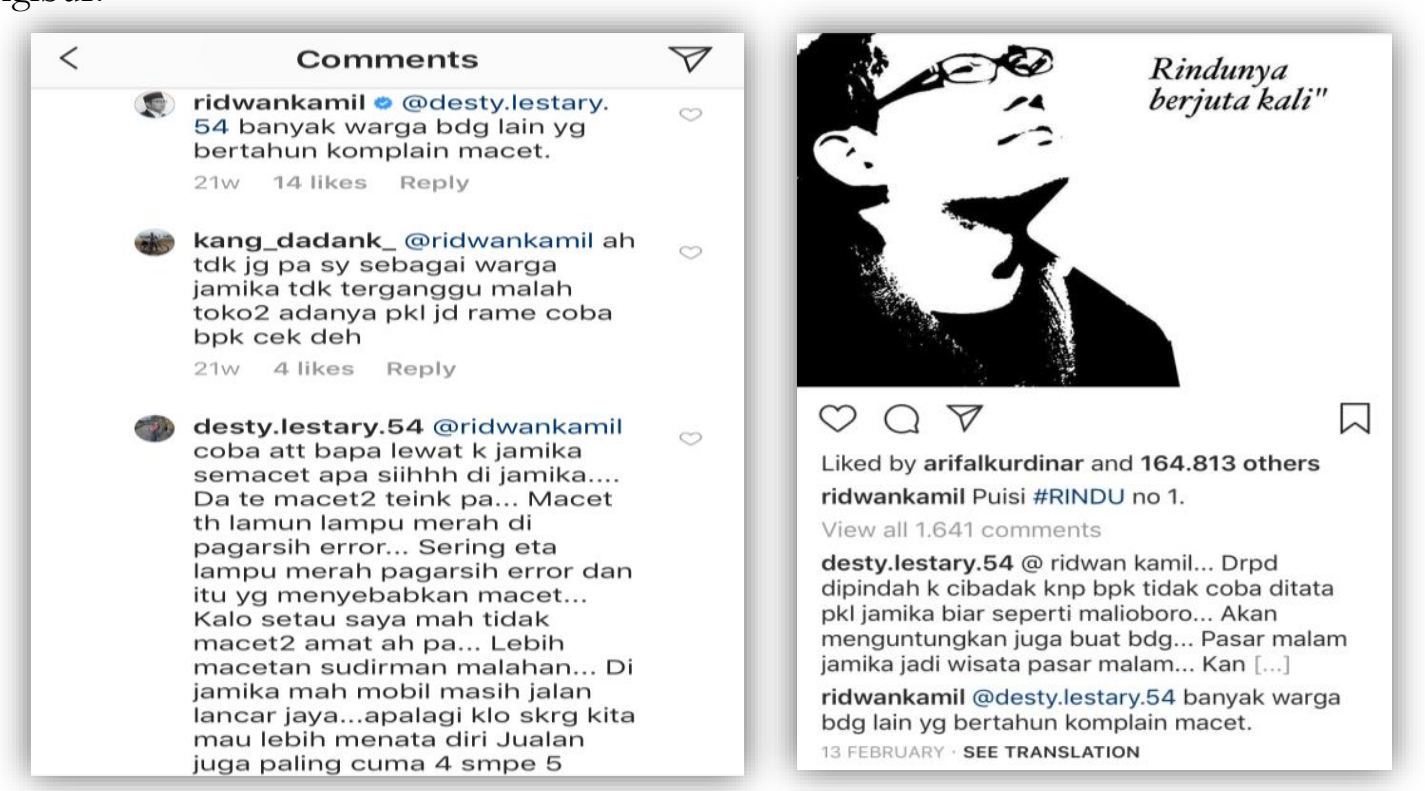

Gambar 1. Komunikasi dua arah antara Ridwan Kamil dan Netizen pada media instagram 
Berdasarkan analisis penulis pada media sosial instagram dengan akun@ridwankamil, gaya komunikasi RK dalam berkomunikasi dengan netizen menjelang pilkada adalah gaya komunikasi dua arah (The equalitarian style). Komunikasi berlangsung dua arah antara RK dengan netizen melalui fitur pesan dan mention pada instagram, netizen yang mengajukan pertanyaan baik terkait pilkada maupun hal lainnya di respon secara langsung. Informasi yang diunggah oleh RK selalu mendapatkan respon netizen baik positif maupun negatif, jumlah komentar pada setiap informasi yang diunggah RK mulai dari 100 komentar hingga empat ribu komentar. Komunikasi bersifat terbuka, dimana netizen dengan mudah menyampaikan kritik, saran, opini, pendapat, dukungan serta harapannya terhadap kepala daerah dimasa mendatang. Dalam hal ini RK juga memberikan respon secara langsung kepada sebagian netizen yang menyampaikan pertanyaan. Gagasan dan pendapat disampaikan oleh netizen secara informal dan santai dengan me-mention langsung akun@ridwankamil tanpa terlihat adanya gap antara netizen dengan calon kepala daerah. Dalam situasi seperti ini diharapkan pesan-pesan yang disampaikan RK dapat dipahami langsung oleh masyarakat, khususnya informasi program kerja.

\section{SIMPULAN}

1. Gaya komunikasi yang digunakan calon kepala daerah menjelang Pilkada Ridwan Kamil (RK) dengan akun@ridwankamil adalah gaya komunikasi dua arah atau The Equalitarian Style.

2. Gaya komunikasi dua arah ini bersifat terbuka, dimana terjadi komunikasi langsung dan pertukaran informasi diantara pengirim pesan dan netizen, komunikasi yang berlangsung bersifat informal dan santai. Dalam hal ini pengirim pesan memberikan respon/feedback secara langsung pada netizen.

\section{DAFTAR PUSTAKA}

Biografi. Biografi Kevin Systrom - Pendiri Instagram, diakses April 2017 melalui halaman http://www.biografiku.com/2013/12/biografi-kevin-systrom-pendiri-instagram_5.html

Cnnindonesia. Ada 22 Juta Pengguna Aktif Instagram dari Indonesia, diakses April 2017 melalui halaman http://www.cnnindonesia.com/teknologi/20160623112758-185-140353/ada22-juta-pengguna-aktif-instagram-dari-indonesia/

Danial, E .2009. Metode Penulisan Karya Ilmiah. Bandung: Laboratorium Pendidikan Kewarganegaraan.

Detikstyle. Media Sosial Terpopuler di Indonesia: Facebook, Instagram, Youtube, diakses April 2017 melalui halaman http://detikstyle.blogspot.co.id/2016/11/media-sosialterpopuler-di-indonesia.html 
Kominfo. Pengguna Internet Indonesia Nomor Enam Dunia. Diakses Juli 2017 melalui halaman https://kominfo.go.id/content/detail/4286/pengguna-internet-indonesianomor-enam-dunia/0/sorotan media

KPU. Empat pasangan calon pilgub jabar 2018 resmi ditetapkan. Diakses Maret 2018 melalui halaman http://www.pikiran-rakyat.com/bandung-raya/2018/02/12/empat-pasangancalon-pilgub-jabar-2018-resmi-ditetapkan-419369

KPU. Tahapan pilkada serentak dimulai. Diakses Maret 2018 melalui halaman http://nasional.kompas.com/read/2017/06/14/12562431/tahapan.pilkada.serentak.20 18.dimulai.ini.jadwal.lengkapnya

Mulyana, Deddy. \& Solatun. 2007. Metode Penelitian Komunikasi. Bandung: PT. Remaja Rosdakarya

Mulyati, Ani. 2014. Panduan Optimalisasi Media Sosial untuk Kementrian Perdagangan RI. Jakarta: Tim Pusat Humas Kementerian Perdagangan RI

Nasrullah, Rulli. 2017. Media Sosial. Bandung: PT Remaja Rosdakarya

Pradana, Arthana. Jurnal Mahasiswa Unesa. Diakses 11 Juli 2018 melalui halaman https://jurnalmahasiswa.unesa.ac.id/index.php/jmtp/article/download/11724/10986.

Prihandini, Puji \& Rachmaniar. 2016. "Bandung Citizen Perceptions Related to Communication Styles of Ridwan Kamil in Social Media”. Prosiding Hiipis. Palembang.

Stewart L. Tubbs dan Sylvia Moss. 1996. Human Communication: Prinsip-prinsip Dasar. Bandung: Remaja Rosdakarya

Sugiyono. 2012. Metode Penelitian Pendidikan Pendekatan Kuantitatif, Kualitatif dan R \& D.Jakarta:Alfabeta

57 SOSIOGLLBAL : Jurnal Pemikiran dan Penelitian Sasiologi, Vol. 2, №. 2, Juni 2018 